\title{
A Difficult Legacy: Human Dignity as the Founding Value of Human Rights
}

\author{
Pawel Luków ${ }^{1}$ (D) \\ Published online: 26 February 2018 \\ (C) The Author(s) 2018. This article is an open access publication
}

Human rights are an unprecedented normative success. They are analysed as elements of international legal and political (Buchanan 2013) practice, or as ethical norms of supra-cultural authority (e.g. Gewirth 1978; Griffin 2008; Kateb 2011; Nussbaum 1997). Despite their limitations and difficulties regarding their enforcement, they enjoy an almost global, even if sometimes rather superficial, recognition. No other set of norms has ever been that widely accepted.

The success of human rights seems to stem crucially from the fact that they were never backed by a substantive account of human nature and the worth, value, or status of a human being. Human dignity did feature in the founding human rights documents, but it was left undefined and its relation to human rights was not specified. Thus, human rights defined a sphere of liberty of individual choice. This situation began to change when the human rights discourse - i.e. human rights legislation, literature, practices, and institutional arrangements - incorporated the thesis that the rights derive from human dignity. A further development of the discourse involved introduction of action constraints that apply to actions that do not harm others or violate others' rights, placing in this way restrictions on individual choice. Examples of such constraints include, among others, the requirement of approval of a research protocol by an independent body if participation in research involving human subjects is to be ethically acceptable or the prohibition of profiting from human body parts, including one's own (for an overview of various uses of dignity in support of action constraints in interational and domestic laws, see McCrudden (2008)).

This linking of human rights and action constraints with human dignity has serious consequences for the acceptance of human rights as widely as possible. Human rights do not rely on a specific substantive view of human nature or human dignity, whereas action constraints seem to involve such a conception to explain-depending on a particular theory of dignity — the value, worth, or status of the human being, who is

Paweł Łuków

p.w.lukow@uw.edu.pl

1 Instytut Filozofii, Uniwersytet Warszawski, Krakowskie Przedmieście 3, 00-927 Warszawa, Poland 
to be protected. The linking of human rights and action constraints with human dignity, and so the need for a substantive view of the value, worth, or status (for all of which the general term 'value' will be used) of human being as the foundation of human rights, can easily jeopardise the wide support for human rights already achieved. Human rights can be easily contested, if they are to be understood as implied by a particular account of human dignity, which must be substantive, theoretically and politically demanding, and may be culturally specific.

One could attempt to defend human rights by rejecting the idea of human dignity as an empty placeholder (Cochrane 2010; Macklin 2003; Pinker 2008). However, such a move does not respond to some important intuitive moral judgments expressed in action constraints, such as the bioethical provisions mentioned above. As long as such judgments and their regulatory counterparts are viewed as important and unless they can be justified merely by prevention of harm to others or violation of others' rights (which is not possible in the case of the examples above), human dignity should remain in the human rights discourse.

Rather than opt for removal of human dignity from the human rights discourse, I shall argue against the founding-value thesis which holds that human dignity is the foundation of human rights or that human rights derive from human dignity "either deductively or with the help of empirical premises" (Waldron 2015). I shall propose that human dignity should remain a part of the human rights discourse because it helps articulate some important moral concerns and can justify the corresponding action constraints. It should not, however, be seen as the foundation of human rights.

The argument proceeds in three steps. The first section explains why the drafters of the founding human rights documents did not define human dignity and did not endorse the founding-value thesis. Without an intention to write a history of the notion of human dignity, the section shows how theoretically rich were the sources from which human dignity arrived in the human rights discourse, how incompatible that original concept was with human rights, and so how politically or culturally demanding its adoption by a world community would be if it were to be included in the human rights discourse. For these reasons, the founding-value thesis should not be seen as an indispensable part of the human rights discourse. The thesis is a residue of a theological doctrine which had been influential before and during the drafting of the first human rights documents. Although in the first half of the twentieth century dignity was present in legislations in some regions (McCrudden 2008), the idea of human dignity as foundation of human rights is a legacy of the mainly Catholic origin of the concept of dignity in the human rights discourse.

The second section, much like the first, identifies key factors that explain the inclusion of the founding-value thesis into the human rights discourse and its growing significance in national and international regulations. First, it was the lack of a definition of human dignity coupled with wide public familiarity with the concept of dignity that was crucial for making it a central element of the German Basic Law, an internationally influential constitution. In this way, human dignity, as protected by law, was a convenient instrument of response to experiences of whole societies. Second, the founding-value thesis resurfaced in the human rights discourse because it helped articulate ethical concerns triggered by challenges stemming from technological and social transformations in numerous countries. These concerns could not be articulated by human rights alone, and so, they were framed as action constraints whose 
justification was located in human dignity. In effect, human dignity was seen as linked to both human rights and action constraints by the founding-value thesis.

The third section illustrates how theoretically challenging the founding-value thesis is for the human rights discourse. For this purpose, a prominent recent interpretation of human dignity in bioethics and biolaw is briefly discussed. The aim of the discussion is not to argue against this construal of human dignity but to show that the differences between human rights and action constraints imply different kinds of arguments and assumptions behind each of them. An attempt to build a conception of human dignity, from which both human rights and action constraints derive, reveals difficulties which question the founding-value thesis when applied to human rights. Moreover, even if a version of such a unified view were possible, the cultural differences regarding human dignity and moral ideas which seem related to it (Düwell et al. 2014; McCrudden 2008; Wong 2017) suggest that it is unlikely to expect support for a single conception of the human condition or human dignity, which would be comparably as wide as the endorsement already enjoyed by human rights. In order to protect this acceptance of human rights, attempts to combine them with action constraints via the foundingvalue thesis and a more precise account of human dignity should be avoided.

In conclusion, it is conjectured that the human rights discourse should be seen as comprising two parallel and (for the time being) unsystematically connected processes: development of human rights and development of action constraints. Human rights, at least those known from the Universal Declaration of Human Rights (UDHR), should be seen as a free-standing device of protection of human agency or individual liberty. They should remain without a specific substantive view of the human condition or a definite theory of human dignity. Since, however, action constraints need to rely on a view of human nature or human dignity, they should be conceptualised as resulting from advances in collective awareness of the fragilities of human existence, which, with time, may result in a more definite substantive view of the human condition and dignity.

\section{Linking Dignity with Human Rights}

Human dignity arrived in the human rights discourse as a result of ideological debates that began at the end of the nineteenth century and continued into the middle of the twentieth century. However, even though an idea of dignity has belonged to the Western philosophical thought since at least late antiquity (Rosen 2012), it has not always been understood in a way similar to many modern interpretations. Arguably, the contemporary idea of human dignity is quite un-traditional (Sensen 2011). It was not a central legal concept, although it did play a role in legal thought (e.g. Pufendorf 1994). While in the beginning of the twentieth century it appeared in a number of constitutions (Iglesias 2001), it was not necessarily conceived of as a foundation of legal norms or as a central legal concept; it often expressed national aspirations or the moral or ideological orientation of constitutional arrangements. Nor did the word dignity have a widely accepted meaning. It gradually found its place in political and legal discourses, retaining much of its vagueness, as can be observed in post-war international human rights regulations. 
One of the first documents which introduced the concept of dignity into the social and political discourse on a larger scale was Pope Leo XIII's encyclical letter Diuturnum of 1881 (Catholic Church. Pope Leo XIII 1942). In it, Leo argues against the belief that the people bestow political power on persons of their choice. In agreement with the Church's tradition, the Pope holds that, ultimately, all power comes from God. The social and political order of a given time issues from God's decision, and the existing class differences are justified because they realise God's will rather than the will of a people (Diuturnum, 5).

As is clear from his concept of the dignity of the human person, in Diuturnum Leo XIII does not endorse democratic, liberal, and often emancipatory ideas. He uses this concept of dignity also in Rerum novarum (1891), the encyclical which is often considered his greatest intellectual achievement. In this encyclical, the concept of dignity of labour is linked to the concept of dignity of the human person from Diuturnum. A prominent feature of this concept of dignity of the human person is that it is not egalitarian (Diuturnum, 17). For Leo XII, every human being has a role to play in society, and that role is determined by, for example, that being's gender or social class (cf. Rosen 2012). The dignity of the human person makes human beings equal in relation to God but not necessarily in their mutual relations within a political society.

Without doubt, following Thomas Aquinas, Leo XIII uses the concept of dignity in various, interrelated meanings. The most general sense of dignity, which emerges from the encyclical, is worth, although in some respects it resembles status, which marks the Roman origins of the concept (Iglesias 2001; Waldron 2012). For Aquinas, "Dignity (dignitas) signifies something's goodness (bonitas) on account of itself" (S. Thomae de Aquino 2012). ${ }^{1}$ It is a value inherent to its possessor, i.e. it is not possessed by that being in virtue of their relation to other worldly beings. Dignity, however, does not pertain to beings of only one kind. The dignity of a being of one kind can differ from the dignity of a being of another kind, which can result in different statuses. The differences in dignity determine the positions which beings of different kinds occupy in the order of existence. The worth of human beings lies in the fact that they have been created in the image of God, and so occupy a high position in the hierarchy of beings. For Aquinas, the human soul

has free will and is incorruptible, and therein man resembles God more than other creatures do. We ought, therefore, to consider the dignity of man as less than the angels but greater than all other creatures. Let us not, therefore, diminish his dignity by $\sin$ and by an inordinate desire for earthly things....(S. Thomae de Aquino 1954) ${ }^{2}$

The Thomism of Leo XIII became a foundational philosophical resource for the social teaching of the Catholic Church on human dignity (Hittinger 2007).

This concept of dignity was later used by Pope Pius XI in his encyclicals of March 1937. In Divini redemptoris (Catholic Church. Pope Pius XI 1937), he opposes

\footnotetext{
1 ,Dignitas significat bonitatem alicujus propter seipsum, utilitas vero propter aliud.' Super Sent., lib. 3 d. 35 q. 1 a. 4 qc. 1 co.

${ }_{2}$ „Non autem quantum ad corpus, sed quantum ad animam, quae est. liberam voluntatem habens et incorruptibilis, in quo magis assimilatur Deo quam ceterae creaturae. Debemus ergo considerare hominem post Angelos digniorem esse ceteris creaturis, et nullo modo dignitatem nostram diminuere propter peccata et propter inordinatum appetitum rerum corporalium, quae viliores sunt nobis, et ad servitium nostrum factae; sed eo modo debemus nos habere quo Deus fecit nos.' a. 1.
} 
communism; in Mit brennender Sorge (Catholic Church. Pope Pius XI 1946) he argues against Nazi nationalism. The two encyclicals expounded the Catholic personalism elaborated by Jacques Maritain in his Integral Humanism of 1936 (Maritain 1973). Pius XI holds that the error of communist ideology stems from treating society as an undifferentiated mass, whose members are seen as passive and driven by external stimuli. Communism "robs human personality of all its dignity, and removes all the moral restraints that check the eruptions of blind impulse" (Divini redemptoris, 10). The Nazi ideology commits an analogous error of rejection of the personal existence of the human being in this life and after, because it "ignores in national life, by confusion of right and utility, the basic fact that man as a person possesses rights he holds from God, and which any collectivity must protect against denial, suppression or neglect". (Mit brennender Sorge, 30). The encyclicals condemn the collectivist perspectives of the two ideologies by uniting human capacity for action with God-given rights in the concept of the human person and their dignity.

The condemnation of the communist and Nazi ideologies and the linking of the dignity of the human person to rights do not imply endorsement of a liberal view of the individual or rights. In his Three Reformers of 1925, Maritain held that the liberal concept of the individual referred to a quality-less being who has no roots in the world and has no moral guidance other than their wishes and interactions with various social and political forces. Individuals and society must recognise human persons, not just human individuals, in their vocation and concreteness, neither of which can be discovered without a metaphysical account of the human being in its totality (Maritain 1970). Accordingly, by rejecting totalitarianisms, Pius XI does not endorse a liberal view of equality: "It is not true that all have equal rights in civil society. It is not true that there exists no lawful social hierarchy". (Divini redemptoris, 33). Emphasising the continuity of his teaching with that of Leo XIII (ibid.), Pius XI sees the individual human being as a member of a God-established metaphysical and social hierarchy in a way akin to that of Aquinas and Leo XII.

According to Maritain and Pius XI, social and political thought must not substitute an unspecified individual for the human person, who is a member of a political society. It is only within a metaphysical account of the location of the human being as a person in the totality of Creation - and an account of this kind is to be found in Christianitythat one can know the norms of individual and social life. The human person is more than a human animal. The human person unites membership in the human species with the unique individuality of a soul capable of reasoning and willing. A person is a rational nature in an individual substance endowed with will and an immortal soul, placed in a God-sanctioned social and political order.

The pre-war personalistic conception of the dignity and rights of the human person is in various respects incompatible with human rights in their post-war understanding. Human rights presuppose social and moral equality of all human beings, and so are incompatible with irremovable status or class divisions. Also, in contrast with the personalistic view of dignity, human rights allow more room for individual choice of the course of one's own life. The suitable social environment for rights, the environment which is set up specifically for their enforcement and protection, is liberal democracy which in many ways conflicts with the hierarchical personalism of the encyclicals. 
Catholic teaching on dignity began to cross the Atlantic to be linked with egalitarian rights before World War II. In a letter of 1938, Pius XI held that "Christian teaching alone gives full meaning to the demands of human rights and liberty because it alone gives worth and dignity to human personality" (the exact phrasings differ in different newspapers, cf. Catholics Urged to Uphold Catholic Liberty Theory 1938; Pope Bids Church to Guard Man's Rights 1938; Pope Pius Calls on Colleges to Guard Liberty 1938). In contrast to the official teaching of the Catholic Church, American bishops interpreted the letter as encouragement for Christians to defend democracy and the constitution to protect the inalienable rights of man (Moyn 2010). It was one of the first instances when dignity was linked to egalitarian rights, which prefigured human rights, as opposed to the rights of the human person.

The association of dignity with human rights was becoming closer due to relocation of a significant part of European intellectual life to North America and the involvement in this process of the successor of Pius XI, Pius XII, during World War II. Maritain played a key role here. Initially, he was critical of human rights, which he correctly saw as different from the rights of the human person, but around 1942, his thought underwent a significant change. In Les droits de l'homme et la loi naturelle, he derives human rights from natural law. This was an important modification in view of the original idea of dignity as the source of obligations. Moreover, in the article 'Christian humanism', published in the magazine Fortune in 1942, Maritain weakened his criticism of human rights that were not rooted in religion, although obviously he did not abandon the Christian conception of the human person as the highest achievement of modern moral thought (Moyn 2011). Even if just superficially, human rights and the dignity of the human person were brought closer.

A similar change occurred in the position of Pope Pius XII who knew and esteemed Maritain. On December 24, 1944 in a Christmas radio speech (Pius XII VI, Quinto anno di Pontificato, 2 marzo 1944-1 ${ }^{\circ}$ marzo 1945), the Pope said that democracy was an acceptable social arrangement if founded on dignity viewed as deriving from imago Dei (Moyn 2010). Despite its initial scepticism about egalitarian human rights and democracy, Catholic doctrine began to see dignity of the human person as possibly (although not unconditionally) reconcilable with human rights and democracy. Although it is hard to say to what extent the change was intentional, this alignment of ideas resulted in a revision in the thought of some leading Catholic intellectuals of the time, whose view of dignity was becoming more and more at home with human rights.

In the context of individual rights, the concept of human dignity was slowly losing a Thomistic-personalistic, non-egalitarian, and antidemocratic quality. This change meant that its links with the concept of the human person and rights were becoming less clear or, perhaps, disappearing. The more the concept of human dignity was removed from its specific religious origin, the more acceptable it could be. Consequently, when the Charter of the United Nations was adopted at the 1945 San Francisco conference, the idea of dignity did not meet serious opposition. Its arrival in the Charter, even if for stylistic reasons, could be relatively smooth and engage the moral sensitivities of the delegates, especially in view of the awareness of the wartime atrocities. The draft of the Charter's Preamble, authored by Jan Smuts, which explained the purpose of the UN, did not use the concept of dignity but that of sanctity and value of the human person and 
human rights. In this draft, the United Nations intended to "re-establish faith in fundamental human rights, in the sanctity and ultimate value of human personality, in the equal rights of men and women and of nations large and small". Believing that the draft was too long, complicated and scholarly, Elizabeth Reynard and Virginia Gildersleeve, who were charged with editorial work on the Preamble, rendered the text into: "to reaffirm faith in the dignity and value of every human being and to maintain his right to live and work in tranquillity and larger freedom" (Gildersleeve 1954). This wording provided the basis for the final version of the Preamble: "to reaffirm faith in fundamental human rights, in the dignity and worth of the human person, in the equal rights of men and women and of nations large and small". In the context of equal rights, the concept of dignity employed in the text is undeniably egalitarian.

Although not without some controversy (McCrudden 2008), this idea of human dignity enters the Universal Declaration of Human Rights in 1948. So reconceived - from confessional and hierarchical to secular and egalitarian-it is not a much theorised idea. Since the declaration is a product of political negotiations rather than a philosophical treatise (Maritain 1998) and so is unsystematic in many ways (cf. Andorno 2007; broad normative reach, heterogeneous requirements, relative to social circumstances, non-static, Beitz 2009), it is no surprise that the concept is rather vague. What is more important, this under-theorisation and imprecision of the concept of human dignity was instrumental in facilitating adoption of the document. And it was deliberate, although it did meet some opposition. Charles Malik, a Lebanese Christian philosopher who co-drafted the declaration, believed that the purpose of the document was to interpret the notion of dignity and worth of the human being which appears in the Preamble of the UN Charter. Yet, despite the acknowledgement of the ethical importance of human dignity by other influential drafters, Malik's proposal was rejected (Glendon 1999; Glendon 2001; Luban 2009). Dignity was intentionally left undefined, and its relation to other values of the Preamble, as well as to human rights, was not specified (Maritain 1949).

Human dignity had therefore two characteristics that made it possible for it to occupy a prominent place in the declaration. Due to earlier ideological and philosophical debates and the work of influential thinkers, the drafters were familiar with some concept of dignity, and some of them were influenced by the idea of human dignity as the foundation of human rights. However, since its theoretical underpinnings were not discussed extensively and it had been gradually linked to human rights during the preceding years, human dignity made its way into the declaration and did not find decisive opponents.

The links between human dignity and human rights were rather loose. The thesis that human dignity founds human rights has not been articulated either in the Charter of the United Nations or in the UDHR. The thesis was not systematically linked to human rights, and so, it was not an irremovable element of the emerging human rights discourse. However, because of its origin as belonging to a theological doctrine, recognisable to some influential figures of the time, human dignity contained the potential to reappear in the human rights discourse in response to new ethical concerns, if those concerns could not be addressed with rights alone. 


\section{The Founding-Value Thesis in the Human Rights Discourse}

The resurgence of the idea of dignity as the founding value, marked in the Covenants, began before 1966. There were at least two factors which made human dignity an attractive moral idea and which inspired the revival. The first was establishment of renewed legal orders after World War II, which saw human dignity as the value to be protected by them. In such remakings of legal arrangements, the idea of dignity, which was known to many influential politicians and social activists, could be readily identified with the dignity from the founding human rights documents. Thus, legal rights could be seen as instruments of protection of human dignity. The second factor that made dignity as a founding value a more and more attractive idea were changes in societies and, later, progress in science and technology. They awakened moral intuitions and concerns which, seemingly, could only be formulated in terms of action constraints that did not have their counterparts in the human rights of the UDHR. These constraints were also conceived of as protections of human dignity, but they put limits on the exercise of individual rights.

An idea of human dignity was appreciated in law before the post-war human rights documents were drafted. It appeared as a basic value in the constitutions of, among others, Mexico (1917), Finland (1919), and Ireland (1937) (Iglesias 2001). In this way, they held an anti-positivistic promise of normative nonarbitrariness and moral stability of legislation. For societies which had gone through a collective trauma, human dignity as the worth of the human being that needs to be protected could be an element of a problem-solving mechanism (Möllers 2009). It played a similar role in the post-war era, this time in the new context of universal natural rights with the idea of human dignity whose Christian origin and indeterminacy facilitated its entry into new legal arrangements.

The drafting of the Basic Law for Germany is a particularly illustrative and influential example of how the Christian origin and indeterminacy of the idea of human dignity helped reject legal positivism. The rejection of positivism starts with Gustav Radbruch's 1946 speech on statutory lawlessness (Radbruch 2006), which he sees as a key theoretical facilitator of implementation of the doctrines of national socialism, and reaches its peak in invocations of natural rights during drafting of the Grundgesetz:

The State ought not to be an end in itself, but must be deliberately confined to fulfilling a subsidiary function vis-à-vis the individual and the various groups within the community. But this is possible only if we abandon the spirit of legal positivism, according to which a legal order made in accordance with the form of legislation always is law, whatever its moral content might be. The State is not for us the source of all law, but is itself subject to the law. There are, as Mr Schmid has observed this morning, rights prior to and superior to the State, resulting from the nature and being of man and his various associations which the State has to respect. Every power of State finds its bounds in these natural, God-given rights of the individual, the family, the local communities of 
town and country, and the occupational groups. It is the task of State to protect and defend these rights. ${ }^{3}$

Legal thought is located in the normative context of universal natural rights. Since many members of the Parliamentary Council, whose task it was to draft the Basic Law, were Christian Democrats, Christian theology provided a natural resource for interpretation of those rights. This theological context also suggested that those rights are Godgiven. Since the new human rights discourse introduced the idea of human dignity very appealing to Christians, but at the same time did not offer its theory, there did not exist theoretical mechanisms that could interfere with some traditional interpretations or conceptual relations. Specifically, it left room for the interpretation of human dignity as the value to be protected by universal natural rights. This, however, was not decided at that time. In agreement with the UDHR, the drafters put protection of human dignity in Art. 1 of the Basic Law. Respect for, and protection of, human dignity was made the duty of all state power, whereas human rights, in the spirit of the declaration, were declared to be the basis of every human society, peace, and justice in the world.

There was no specific conception of human dignity shared by all members of the Parliamentary Council. For this reason, they did not share a conception of the relation between dignity and rights. Many delegates could draw on Epictetus or Luther when thinking of human dignity to make the notion appealing to both religious and nonreligious members of the council. They did not rely on the concept of dignity which is standardly attributed to I. Kant whose "name was not even mentioned during the framers' debates on Article 1" (Goos 2013; Möllers 2009). References to Kant or a vocabulary drawn from his writings became an important component of the German constitutional law after the Grundgesetz had been passed (for a recent example, see the aircraft hijacking case: BVerfG 2006). In an effort to secure the widest possible support for the idea of human dignity and for the Basic Law, and in a similar way to the drafters of the UDHR, some delegates argued that dignity should be seen as an un-interpreted concept (Goos 2011; Goos 2013). Despite these differences and uncertainties, the delegates did share some version of the belief that human dignity is "the intrinsic, non-negotiable non-fungible worth that inheres in every human being" (Waldron 2012). Their shared view of human dignity was probably closer to the undefined dignity of the declaration rather than to any specific philosophical or cultural view. In this way, the idea of human dignity as a value was a stepping stone to the foundingvalue thesis: since it was a value to be protected by the state, human rights could be

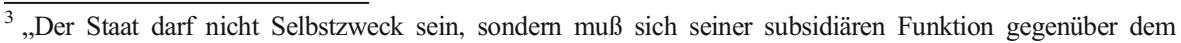
Einzelmenschen und den verschiedenen innerstaatlichen Gemeinschaften stets bewußt bleiben. Das ist aber nur möglich, wenn wir uns endgültig von dem Geiste des Rechtspositivismus abwenden, wonach der in ordnungsmäßiger Form zustandegekommene staatliche Gesetzesbefehl immer Recht schafft ohne Rücksicht auf seinen sittlichen Inhalt. Der Staat ist für uns nicht die Quelle allen Rechts, sondern selbst dem Recht unterworfen. Es gibt, wie auch der Herr Kollege Schmid heute vormittag hervorhob, vor- und überstaatliche Rechte, die sich aus der Natur und dem Wesen des Menschen und der verschiedenen menschlichen Lebensgemeinschaften ergeben, die der Staat zu respektieren hat. Jede Staatsgewalt findet ihre Begrenzung an diesen natürlichen, gottgewollten Rechten des einzelnen, der Familien, der Gemeinden, der Heimatlandschaften und der beruflichen Leistungsgemeinschaften. Es ist die Aufgabe des Staates, diese Rechte zu schützen und zu wahren.' Prof. A. Süsterhenn's speech in (Der Parlamentarische Rat 1948-1949. Akten und Protokolle. 14 Bände. BAND 9 Plenum 2010), p. 55.
} 
seen as instruments of that protection, i.e. potentially, human dignity was the value from which human rights could derive.

This kind of potential remained a matter of interpretation rather than official assertion or part of the human rights discourse until the International Covenant on Civil and Political Rights and the International Covenant on Economic, Social and Cultural Rights were adopted in 1966 (e.g. Dicke 2002; Henkin 1998; Weisstub 2002). The opening sentences of their preambles repeat the phrase known from the Charter and the UDHR that human dignity and human rights are "the foundation of freedom, justice and peace in the world". However, they add to this statement that human rights "derive from the inherent dignity of the human person". This idea is reflected in a 'transitional' form in Art. 13.2 of the International Covenant on Economic, Social and Cultural Rights, which requires compulsory primary education.

According to this article, citizens not only have a right to primary education but they are also required to undergo it. The right to primary education is therefore not simply a right one may choose to exercise or not. It can also be demanded from a citizen that they undergo primary education. However, individual rights alone are not sufficient to justify such an obligation, as its main beneficiary is the right holder who may refuse to exercise their right. One could point out that undereducated individuals may be burdens to others, but there is no hint of this idea. However, in light of the Preamble's announcement that human rights derive from human dignity, a different, even if supplementary, reason for the requirement of compulsory primary education can be reconstructed. Primary education is obligatory because citizens of modern societies need some level of education for fruitful participation in society, which is part of a successful human life. This line of reasoning obviously presupposes a view of the worth of an individual, which can be identified with human dignity.

Whether the drafters of the Covenant actually supported an argument like the one in the paragraph above or not, it is telling that the founding-value thesis is officially introduced in a document which contains an individual action constraint. This constraint clearly responds to an ethical concern which grew out of scientific and technological change. Being viewed as the founding value to be protected, human dignity could now be protected with specific action constraints on right holders. If the argument above was part of the rationale for the Art. 13.2, it could be because it was becoming clear that rights alone cannot respond to some important intuitive judgments regarding actions which do not harm others or violate their rights and can be considered to be legitimate exercises of rights. Additionally, it could be noted that Art. 13.2 protects the dignity of both those who are not able to exercise their rights (e.g. due to their immaturity) and those who are.

Analogous reasons - i.e. technological change and protection of human dignity against harms agents may inflict on themselves - are explicitly offered in a later regulatory human rights response to developments in life sciences and biomedicine. Articles 16 and 21 of the Oviedo Convention of 1997 are apt examples of reactions to such concerns. They prohibit actions which do not harm others or violate their rights on the ground that they are disrespectful of human dignity. Art. 16 requires that protocols of research involving humans be reviewed for their ethical acceptability by an independent body. Art. 21 prohibits profiting from sale of human body parts (including one's own) for the purpose of transplantation (Council of Europe 1997a; for an example from a different area, see Manuel Wackenheim v. France, Communication No. 854/ 
1999, U.N. Doc. CCPR/C/75/D/854/1999 (2002) 2007). The provisions of Art. 16 of the convention are further specified in Art. 9 of the Additional Protocol to the Convention on Human Rights and Biomedicine concerning Biomedical Research (Council of Europe 2005a). The Explanatory Report to this Protocol provides that review of research protocols is required in order to protect, among others, the dignity of research participants (Council of Europe 2005b). In a more direct way, the Explanatory Report to the Convention provides that sale of human body parts (whether those of others or one's own) is an affront to human dignity (Council of Europe 1997b). The justifications of those constraints are linked to human dignity as "the essential value to be upheld" (Council of Europe 1997b). It should be stressed that these action constraints, which protect human dignity rather than freedom of choice, apply to persons who are capable of consent and not only to those who are not able to consent (as in Art. 17 of the Convention).

Such provisions clearly limit exercise of rights by individuals. Participation in highrisk research (even if its participants are well-informed of the risk) or selling one's own body parts (under protections against discrimination, manipulation, or exploitation) can be regarded as an exercise of one's rights, such as the right of self-determination, and as a source of great benefits to others by promoting medical progress or saving organ recipients' lives (Radcliffe-Richards et al. 1998; Shaw 2014). However, provisions such as these show that rights alone do not afford sufficient reasons to justify every individual action which respects them. Some of those actions - even if they are exercises of rights, do not harm others, or generate significant benefits to others-are believed to conflict with human dignity.

Human dignity can be an attractive conceptual tool for articulation of some intuitive moral insights, which - as also some human rights theorists who understand human dignity in terms of protection of agency or autonomy admit (Griffin 2008; Möller 2012) - cannot be expressed with human rights alone. It was possible to include such judgments within the human rights discourse because human dignity was recognised as a value, and then, due to the legacy of the formation of the discourse, was understood as the founding value of human rights. When the protective role of human rights appeared insufficient for articulation of some important intuitive judgments, the founding role of human dignity became attractive. This time, however, it is seen as founding action constraints and human rights.

By the end of the twentieth century, human dignity as a founding value played a double role. First, due to lack of precise definition in the founding human rights documents, and the need to establish a more secure political order in the post-war era, human dignity was an attractive moral idea. It could be interpreted variously. The influence of Catholic moral thought in the process of formation of the human rights discourse suggested interpretations which see it as a founding value. This potential was initially actualised in the Covenants of 1966, which stated that human rights "derive from the inherent dignity of the human person". Second, in response to ethical concerns aroused, among others, by some political and societal changes, and, later, by developments in biology and medicine, particularly in the last three decades, human dignity was more and more often appealed to as the source of constraints on actions of right holders, making human dignity more prominent and influential as the founding value. Human dignity came to be seen as the founding value of both human rights and action constraints applying to right holders. 


\section{The Dualities of Human Dignity as the Founding Value}

Incorporation of the founding-value thesis into the human rights discourse as applying to both human rights and human dignity seems attractive, at least initially, because it promises a theoretical and axiological unity according to which all key ethical standards derive from a common foundation. However, it is highly doubtful if such a unity could be achieved because human rights, at least the first-generation human rights such as those of the UDHR, and action constraints are of different natures. Human rights determine a sphere of individual liberty against other subjects (governments or individuals); action constraints place limits on exercise of rights which are justified by prevention of harms to the agent in question or by protection of an impersonal value. What constitutes a harm within the sphere protected by rights is left to the right holder, whereas in the case of action constraints, harms are not defined by right holders or at least not exclusively by them. Rights are silent about the specific good of the right holders, whereas action constraints seem to presuppose an impersonal conception of the good or value to be protected.

Deryck Beyleveld and Roger Brownsword's account of human dignity (Beyleveld and Brownsword 2001) as the ground for both human rights and action constraints illustrates this difference well. More importantly, it exemplifies the difficulties that stem from reliance on the founding-value thesis in a reconstruction of human dignity. The thesis is hoped to provide a unified foundation for both human rights and action constraints but the differences between the arguments that support human rights and those that support action constraints suggest a dualist conception of human dignity, in which some elements are redundant and other controversial. As a whole, such an approach may undermine some central components of the human rights discourse.

In their reconstruction of human dignity, Beyleveld and Brownsword depend on Alan Gewirth's dialectically necessary derivation of rights from the necessary conditions of action: freedom and well-being (Gewirth 1978). Gewirth argues that every human agent must accept the claim that freedom and well-being are necessary goods whose possession is the precondition of action. Every agent must therefore see these conditions as objects of their generic rights. Recognition of those rights implies that other agents have corresponding obligations of non-interference with the agent's pursuit of the necessary conditions of action (goods). Since the principle of universalisability requires the same treatment of relevantly similar cases, the recognition of one's own rights to the necessary goods implies that every other agent has the same generic rights to them. And vice versa: denial of such rights of others implies denial of one's own rights of the same kind; recognition of the obligation of others not to interfere with one's own pursuits of the necessary goods implies recognition of one's own obligation not to interfere with others' pursuits of those necessary goods.

Gewirth's argument does not identify action constraints in the sense explained earlier in this paper. It does not presuppose any substantive account of human nature with its specific goods; the rights that agents have are those against others (individuals or institutions), and their obligations are implied by those generic rights. None of those components of Gewirth's argument produce norms that apply directly to self-regarding actions that do not involve others. Such actions cannot violate others' generic rights or imply obligations on their part because these actions are self-regarding. 
Despite their faith in the argument (cf. Beyleveld 1991), Beyleveld and Brownsword see this limitation. To justify action constraints, which are part of the human rights discourse, they offer a substantive view of human beings and their worth or status. For this purpose, they draw on Søren Kierkegaard and Erich Fromm to argue that human beings experience an existential anxiety that originates in the fear of extinction and commands some normative response. Beyleveld and Brownsword do not insist on these particular conceptions. Rather, they emphasise the need to address this anxiety in order to complete an account of human dignity as the source value of both human rights and action constraints.

What is characteristic for Beyleveld and Brownsword's account of human dignity is the presence of dualities which question the idea of deriving both human rights and action constraints from human dignity. First, the fact that the dialectically necessary derivation of rights from agency needs to be supplemented with the quasi-empirical (i.e. not dialectically necessary) argument from existential anxiety shows that agency alone cannot find action constraints other than those which are justified by respect for the rights of others. The more important aspect of their argument, however, is that unlike the dialectically necessary derivation of rights from agency, which is intended to identify necessary claims regarding individual rights, the argument from existential anxiety is based on contingent claims that found action constraints. In consequence, the intention to derive both human rights and action constraints from human dignity results in an account of dignity with two heterogeneous and mutually independent components.

Second (and relatedly), the two components of Beyleveld and Brownsword's view of human dignity differ with regard to the strength of argument that backs derivation of rights as opposed to derivation of action constraints. The account of human condition inspired by Kierkegaard and Fromm is intended as the source of action constraints, which are the more controversial part of the human rights discourse. Yet, the argument for them is much weaker than the Gewirthian derivation of rights. Aware of this, Beyleveld and Brownsword do not insist on this particular conception and are open to alternatives. In this way, however, they may suggest that the rights of the human rights discourse, as opposed to action constraints, do not require a substantive view of human dignity.

Third, since Beyleveld and Brownsword's account of human dignity is based on a view of the human condition, it is not clear what justifies their choice of such a dual conception. A single or unified view of the human condition could be more appropriate for derivation of both rights and action constraints. One might argue more traditionally (e.g. as described in the first section above) that the human condition and the worth of the human being found obligations of human beings, and these obligations justify their rights. Some of those obligations could be other-regarding, whereas other obligations could be self-regarding, i.e. they could be action constraints derived from recognition of the special worth or status of humans. If Beyleveld and Brownsword chose this route of argumentation, they would not need Gewirth's argument, which justifies those restrictions on exercise of one's rights that protect the rights of others. A possible explanation of Beyleveld and Brownsword's decision might be that they wanted to preserve the metaphysically non-committing character of human rights from the human rights discourse. This, however, would suggest that it is advisable not to derive human rights from human dignity, although human dignity might be the foundation on which action 
constraints rest. And attempt to build a conception that identifies a shared foundation for both human rights and action constraints would require a specific substantive view of human dignity.

The above analysis of Beyleveld and Brownsword's view shows that, as appreciated by some scholars (Den Hartogh 2014), a vindication of human rights, if it were to be sought, should be expected to differ from justification of action constraints. Rights, as Beyleveld and Brownsword make it clear in their proposal, can be identified without a specific substantive account of the human agent, whereas action constraints require such a conception to determine, among others, what self-regarding actions should be prohibited. An attempt to derive both rights and action constraints of the human rights discourse from human dignity reveals the dualities which seem to question the idea of derivation of both human rights and action constraints from human dignity. From this perspective, the decision of the drafters of the founding human rights documents not to derive human rights from human dignity can be viewed not only as evidence of pragmatism motivated by the desire to reach agreement regarding a catalogue of rights but also as an awareness that their diverse and sometimes irreconcilable views of the human good or flourishing do not leave much room for agreement on a substantive conception of a founding value of the human being.

Adoption of the founding-value thesis in the human rights discourse leads therefore to a situation which the drafters of the founding human rights documents wanted to avoid. They recognised that a view of human dignity from which human rights are to derive would be at least as difficult to adopt widely as the theological doctrine from which the concept of human dignity was originally brought into the human rights discourse. In order to win support for the widest possible moral and legal revival, human dignity was left undefined and its link to human rights was not specified. The reasons recognised by the drafters were both theoretical and practical-political. Theoretically, it would be over-ambitious to develop a substantive account of human dignity as a universally recognised value. Practically and politically, in view of the ideological changes, whose momentum had been increasing, such an endeavour would be simply unrealistic.

\section{Conclusion}

It was argued in the foregoing discussion that the thesis, according to which human dignity is the founding value of human rights, should be abandoned if human rights (or a core portion of them) are to maintain their wide acceptance, and the human rights discourse is to respond to intuitive moral judgments motivated by developments in societies and technology. It was not suggested that human dignity should be removed from the human rights discourse. Nor was it claimed that, in the human rights discourse, action constraints cannot be construed as deriving from human dignity (this issue requires separate treatment). The scepticism expressed was about the idea of human dignity as the ground for human rights.

However, new ethical concerns which emerge in the rapidly changing world do need to be addressed, and an adequate approach to both human rights and action constraints is required. Since, as shown above, unification of human rights and action constraints via the founding-value thesis should be avoided, the two kinds of norms-action 
constraints and human rights - could be kept relatively independent of each other. As suggested even by some accounts of human rights that make agency the defining term of human rights, a possible, pragmatically driven theoretical direction might be to treat human rights as free-standing instruments that articulate basic requirements of agency or individual liberty. Such a pragmatic and political view of human rights is reinforced by the current human rights discourse in the international arena. Appeals to human dignity do not seem necessary; an international consensus regarding human rights can be sufficient.

Nevertheless, since due to some moral intuitions new concerns need to be addressed, and one can expect that they will emerge in the near future more and more frequently, both action constraints and human dignity should remain in the human rights discourse. Development of an account of the relation between human dignity, human rights, and action constraints lies beyond the scope of the present article. Only a most general outline of such an account can be offered here.

It might be proposed to construe action constraints as components of an evolving and collective understanding of the human condition, which results from more and more global discussions and negotiations of various aspects of human individual and social life vis-à-vis new challenges. So interpreted, action constraints could be seen as developing in a piecemeal manner as parts of a gradually emerging understanding of human dignity. In agreement with the intentions of the drafters of the founding human rights documents, the 'comprehensive vagueness' (Harris 1998; Kuhse 2000) of human dignity could be its strength, not a weakness, in this process. Human dignity would not be a 'conversation stopper' (Birnbacher 1986) but an inspiration for dialogue. It would be a project under construction which reflects human collective awareness of their own fragility in the face of new challenges posed by society and technology.

Acknowledgments This work was supported by the National Science Centre, Poland, under Grant no. 2014/15/B/HS1/03829.

Open Access This article is distributed under the terms of the Creative Commons Attribution 4.0 International License (http://creativecommons.org/licenses/by/4.0/), which permits unrestricted use, distribution, and reproduction in any medium, provided you give appropriate credit to the original author(s) and the source, provide a link to the Creative Commons license, and indicate if changes were made.

\section{References}

Andorno R (2007) Global bioethics at UNESCO: in defence of the Universal Declaration on Bioethics and Human Rights Journal of Medical Ethics 33:150-154 https://doi.org/10.1136/jme.2006.016543

Beitz CR (2009) The idea of human rights. Oxford University Press, Oxford; New York

Beyleveld D (1991) The dialectical necessity of morality: an analysis and defense of Alan Gewirth's argument to the principle of generic consistency. University of Chicago Press, Chicago

Beyleveld D, Brownsword R (2001) Human dignity in bioethics and biolaw. Oxford University Press, Oxford; New York

Birnbacher D (1986) Ambiguities in the concept of Menschenwuerde. In: Bayertz K (ed) Sanctity of life and human dignity. Kluwer Academic, Dordrecht, Boston,

Buchanan AE (2013) The heart of human rights. Oxford University Press, Oxford

BVerfG (2006) Urteil des Ersten Senats vom 15. Februar 2006-1 BvR 357/05 - Rn. (1-156), http://www. bverfg.de/e/rs20060215_1bvr035705.html. 
Catholic Church. Pope Leo XIII (1942) On civil government; encyclical letter of Pope Leo XIII. Diuturnum. The Paulist press, New York,

Catholic Church. Pope Pius XI (1937) Encyclical letter of His Holiness, Pope Pius XI (Divini Redemptoris) Atheistic communism. Knights of Columbus, New Haven, Conn.,

Catholic Church. Pope Pius XI (1946) Mit brennender Sorge: das päpstliche Rundschreiben gegen den Nationalsozialismus und seine Folgen in Deutschland. Das Christliche Deutschland, 1933 bis 1945 Katholische Reihe, vol Heft 1. Herder, Freiburg im Breisgau

Catholics Urged to Uphold Catholic Liberty Theory (1938).

Cochrane A (2010) Undignified bioethics Bioethics 24:234-241 https://doi.org/10.1111/j.14678519.2009.01781.x

Council of Europe (1997a) Convention for Protection of Human Rights and Dignity of the Human Being with Regard to the Application of Biology and Biomedicine: Convention of Human Rights and Biomedicine (CETS No. 164). Council of Europe, Oviedo.

Council of Europe (1997b) Explanatory Report to the Convention for the protection of Human Rights and Dignity of the Human Being with regard to the Application of Biology and Medicine: Convention on Human Rights and Biomedicine. Council of Europe, Oviedo.

Council of Europe (2005a) Additional Protocol to the Convention on Human Rights and Biomedicine, concerning Biomedical Research (CETS No. 195). Council of Europe, Strasbourg.

Council of Europe (2005b) Explanatory Report to the Additional Protocol to the Convention on Human Rights and Biomedicine concerning Biomedical Research. Council of Europe, Strasbourg.

Den Hartogh G (2014) Is human dignity the ground of human rights? In: Düwell M, Braarvig J, Brownsword R, Mieth D (eds) The Cambridge handbook of human dignity: interdisciplinary perspectives. Cambridge University Press, Cambridge, pp 200-207.

Der Parlamentarische Rat 1948-1949. Akten und Protokolle. 14 Bände. BAND 9 Plenum (2010). Oldenbourg Wissenschaftsverlag, Berlin, Boston. https://doi.org/10.1524/9783486702385

Dicke K (2002) The founding function of human dignity in the Universal Declaration of Human Rights In: Kretzmer D, Klein E (eds) The concept of human dignity in human rights discourse. Kluwer Law International, The Hague; New York, pp 111-120.

Düwell M, Braarvig J, Brownsword R, Mieth D (2014) The Cambridge handbook of human dignity: interdisciplinary perspectives. Cambridge University Press, Cambridge.

Gewirth A (1978) Reason and morality. University of Chicago Press, Chicago

Gildersleeve VC (1954) Many a good crusade; memoirs. Macmillan, New York,

Glendon MA (1999) Foundations of human rights: the unfinished business. American Journal of Jurisprudence 44, 1-14.

Glendon MA (2001) A world made new : Eleanor Roosevelt and the Universal Declaration of Human Rights. 1st edn. Random House, New York

Goos C (2011) Innere Freiheit: eine Rekonstruktion des grundgesetzlichen Würdebegriffs. V\&R Unipress, Bonn

Goos C (2013) Restoring human dignity in Post-Nazi Germany. In: McCrudden C (ed) Understanding human dignity. Oxford University Press, New York.

Griffin J (2008) On human rights. Oxford University Press, Oxford; New York

Harris J (1998) Clones, genes, and immortality: ethics and the genetic revolution. Oxford University Press, Oxford; New York

Henkin L (1998) Religion, religions, and human rights The Journal of Religious Ethics 26:229-239

Hittinger R (2007) Introduction to modern catholicism. In: Witte J, Alexander FS (eds) The teachings of modern Orthodox Christianity on law, politics, and human nature. Columbia University Press, New York,

Iglesias T (2001) Bedrock truths and the dignity of the individual Logos: A Journal of Catholic Thought and Culture 4:114-134

Kateb G (2011) Human dignity. Belknap Press of Harvard University Press, Cambridge, MA

Kuhse H (2000) Is there a tension between autonomy and dignity. In: Kemp P, Rendtorff J, Mattsson N (eds) Bioethics and biolaw, vol 2. Rhodos International, Copenhagen, pp 61-74.

Luban D (2009) Human dignity, humiliation, and torture Kennedy Institute of Ethics Journal 19:211-230 https://doi.org/10.1353/ken.0.0292

Macklin R (2003) Dignity is a useless concept BMJ 327:1419-1420 https://doi.org/10.1136 /bmj.327.7429.1419

Manuel Wackenheim v. France, Communication No. 854/1999, U.N. Doc. CCPR/C/75/D/854/1999 (2002) (2007). In: Committee UNHR (ed) Selected Decisions under the Optional Protocol, Seventy- Fifth to Eighty- Fourth Sessions (July 2002- March 2005) United Nations Publications, New York, 
Maritain J (1949) Introduction. In: UNESCO (ed) Human Rights: Comments and Interpretations : a Symposium Edited by Unesco with an Introduction by Jacques Maritain. Columbia University Press, New York,

Maritain J (1970) Three reformers: Luther, Descartes, Rousseau. Apollo editions,, vol A-266. Crowell, New York,

Maritain J (1973) Integral humanism; temporal and spiritual problems of a new Christendom. University of Notre Dame Press, Notre Dame, Ind.

Maritain J (1998) Man and the state. Catholic University of America Press, Washington, D.C.

McCrudden C (2008) Human dignity and judicial interpretation of human rights European Journal of International Law 19:655-724

Möller K (2012) The global model of constitutional rights. Oxford constitutional theory, 1st edn. Oxford University Press, Oxford

Möllers C (2009) Democracy and human dignity: limits of a moralized conception of rights in German constitutional law Israel Law Review 42:416-439

Moyn S (2011) Personalism, community and the origins of human rights. In: Hoffmann S-L (ed) Human rights in the twentieth century. Cambridge University Press, Cambridge; New York, pp 85-106.

Moyn S (2011) Jacques Maritain, Christian new order, and the birth of human rights. In: Bonanante L, Papini $\mathrm{R}$, Sweet W (eds) Intercultural dialogue and human rights. Council for Research in Values and Philosophy, Washington, DC.

Nussbaum MC (1997) Capabilities and human rights Fordham Law Review 66:273-300

Pinker S (2008) The stupidity of dignity The New Republic http://www.newrepublic.com/article/the-stupiditydignity

Pius XII VI, Quinto anno di Pontificato, 2 marzo 1944 - $1^{\circ}$ marzo (1945) Radiomessaggio di sua santità Pio XII ai popoli del mondo intero. In: Discorsi e Radiomessaggi di Sua Santità Pio XII. pp 235-225

Pope Bids Church to Guard Man's Rights (1938, October 13), New York Times. p. 1.

Pope Pius Calls on Colleges to Guard Liberty (1938, October 13), Chicago Tribune. p 9.

Pufendorf S (1994) The political writings of Samuel Pufendorf. Oxford University Press, New York

Radbruch G (2006) Statutory lawlessness and supra-statutory law (1946) Oxford Journal of Legal Studies 26: 1-11 https://doi.org/10.1093/ojls/gqi041

Radcliffe-Richards J et al. (1998) The case for allowing kidney sales The Lancet 351:1950-1952 https://doi. org/10.1016/S0140-6736(97)08211-1

Rosen M (2012) Dignity : its history and meaning. Harvard University Press, Cambridge, Mass.

S. Thomae de Aquino (1954) Symbolum Apostolorum. http://www.corpusthomisticum.org/csv.html. Accessed 21.02.2018

S. Thomae de Aquino (2012) Scriptum super Sententiis. http://www.corpusthomisticum.org. Accessed 21.02.2018

Sensen O (2011) Human dignity in historical perspective: the contemporary and traditional paradigms European Journal of Political Theory 10:71-91https://doi.org/10.1177/1474885110386006

Shaw D (2014) The right to participate in high-risk research The Lancet 383:1009-1011 https://oi. org/10.1016/S0140-6736(13)61575-5

Waldron J (2012) Dignity, rank, and rights. Oxford University Press, New York

Waldron J (2015) Is dignity the foundation of human rights? In: Cruft R, Liao SM, Renzo M (eds) Philosophical foundations of human rights. Oxford University Press, Oxford, pp 117-137.

Weisstub DN (2002) Honor, dignity, and the framing of multiculturalist values. In: Kretzmer D, Klein E (eds) The concept of human dignity in human rights discourse. Kluwer Law International, The Hague; New York, pp 263-296.

Wong D (2017) Dignity in Confucian and Buddhist thought. In: Debes R (ed) Dignity: a history. Oxford University Press, New York, pp 67-72. 